\title{
Sensitivity towards the reaction of outsiders as ethical motivation in early Christian paraenesis
}

\begin{abstract}
Author:
Andrie B. du Toit ${ }^{1}$

Affiliation:

${ }^{1}$ Department of New

Testament Studies, University

of Pretoria, South Africa

Note:

Prof. Dr Andrie du Toit is professor emiritus at the University of Pretoria, South Africa, and a research associate of Prof. Dr Kobus Kok at the same institution in the research field of mission and ethics in the New Testament.

\section{Correspondence to:}

Andrie du Toit

Email:

andriedt@icon.co.za

Postal address:

PO Box 92345, Mooikloof

0059, Pretoria, South Africa

Dates:

Received: 09 Jan. 2012

Accepted: 31 Mar. 2012

Published: 29 June 2012

How to cite this article:

Du Toit, A.B., 2012,

'Sensitivity towards the reaction of outsiders as ethical motivation in early Christian paraenesis', HTS Teologiese Studies/ Theological Studies 68(1), Art. \#1212, 7 pages. http:// dx.doi.org/10.4102/hts. v68i1.1212
\end{abstract}

2012. The Authors. Licensee: AOSIS OpenJournals. This work is licensed under the Creative Commons Attribution License.
Early Christian documents contain many indications of a sensitivity towards the presence of non-Christians in their environment, a sensitivity which increased as the expectation of an imminent end receded. This study concentrated on those paraenetic texts which maintain that Christians, in the shaping of their lifestyle, should reckon with the reaction of outsiders. Two trajectories, a negative as well as a positive one, were identified. Subsequently the double perlocutionary aim of these 'outsider sayings' was scrutinised. A final word summarised the hermeneutic implications of these sayings for today. Since in many societies the credibility of the gospel message is under pressure, exemplary living is a sine qua non.

\section{Introduction}

As the Christian message moved from its original Jewish home into Gentile surroundings, the first Christians became increasingly conscious of their non-Christian environment. They were obliged to responsibly position themselves and their ethos as Christians within this environment. As a result, early Christian documents and especially the paraenetic texts, contain many indications of a sensitivity towards the presence of non-Christians and of the individual, social and political responsibilities expected of believers. Already in the very first early Christian document that we possess, namely Paul's first letter to the Thessalonians, this sensitivity is apparent, as Paul urges his addressees:

put your pride in leading an orderly life, minding your own business and working with your own hands,

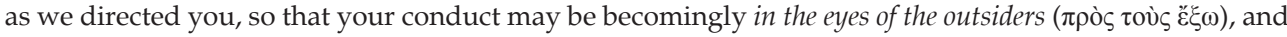
you may not be dependent on anyone. (1 Th 4:11-12)

At the other end of the early Christian period, this sensitivity found its classical expression in 2 Clement 13.

A second factor came into play: The delay of the parousia. As the expectation of an imminent end receded, Christian leaders increasingly realised that they had to advise their constituencies about the realities of living for a prolonged period within various societal structures. Understandably, therefore, admonitions on the necessity to reckon with the reactions of outsiders increased substantially, as is evident from the later early Christian documents. In this article, I shall refrain from addressing the much broader issue of the ethical responsibility of early Christians towards their societies. Instead, I shall concentrate on those texts where the reaction of outsiders are specifically in focus and applied as ethical motivation.

In the last decades, much attention has been given to the concept of 'the others' or 'the outsiders' in the early Christian period, especially from a social scientific perspective. ${ }^{1}$ In fact, 'insiders', 'outsiders', 'the others', as well as 'identity' have become buzzwords in biblical studies. At the same time, the reference to the outsiders and insiders shift continuously. Janus-like it changes, depending on the perspective applied. From an early Christian perspective the followers of Jesus Christ normally regarded themselves as insiders, and the non-followers or non-believers as outsiders or others. ${ }^{2}$ This will also be the perspective of this study. I shall focus on those early Christian texts which maintain that Christians, in the shaping of their lifestyle, should reckon with the reaction of outsiders. For the sake of brevity and convenience I shall henceforth speak of these ethical statements as the 'outsider sayings'.

In his ground-breaking study of the nature of New Testament paraenesis, Martin Dibelius ([1921] 1964) took the position that the ethical injunctions, since they derived to a considerable extent

1.To mention only a very few: Elliott (1981 [esp. 78-84]); Neusner and Frerichs (1985); Kopas (1993); LaHurd (1997); Stolz (2001); Richard (2004); Pietersen (2004); Schwarz (2006); Ascough (2007); Crook and Harland (2007); Horrrell (2007); Dunning (2009).

2.The mentioned shifting of reference according to the vantage point applied should throughout be kept in mind. For instance, the early Christians could, from a different perspective, also describe themselves as 'others'. It is fascinating to observe how early Christian documents such as 1 Peter, Hebrews, the Epistle to Diognetus etc. apply the notion of otherness in order to define Christian identity see in this regard especially Dunning (2009). 
from the 'volkstümlichen Ethik des Altertums', are more or less timeless and a-contextual. ${ }^{3}$ As a general characterisation, however, this is not entirely correct. Although not all paraenetic utterances in the New Testament are equally contextually embedded, many, if not most of them have some contextual connotation. ${ }^{4}$ At the same time - and this is the important truth in the position of Dibelius - ethical injunctions, whatever their contingent situation, usually tend towards the typical and universal. In this study I shall concentrate on the latter. Without ignoring the specific literary and situational, that is, the contingent aspects, I shall endeavour to extrapolate some basic themes or trends relating to the ethical sensivity of early Christian writers to the reactions of outsiders. ${ }^{5}$ Firstly, I shall pay attention to the most prominent terms for those outside the Christian fold, yet without restricting myself to these. Secondly, I shall explore the main trajectories emerging from the outsider sayings. And finally the perlocutionary goal of these sayings will come into focus.

\section{Some prominent terms used for non-Christians \\ Oi है $\xi \omega /$ है $\xi \omega \theta \varepsilon v$}

Naturally, the oldest use of oi $\check{\varepsilon} \xi \omega$ and oi $\check{\varepsilon} \xi \omega \theta \varepsilon v^{6}$ would be references to people finding themselves literally outside of a defined physical area, for example, a city or a country. Instances of such references abound and they need not be documented here. We are concerned with the figurative use of these phrases, referring to those persons who find themselves outside of a distinct grouping. ${ }^{7}$ Xenophon (Hellenica Book 2 ch. 4 sect. 1, line 3) uses of $\tilde{\varepsilon} \xi \omega$ for those not being on the Lacedaemonian city roll. In his De Vita Pythagorica (ch. 35 sect. 252, line 11), Iamblicus uses oi $\ddot{\varepsilon} \xi \omega$ in referring to non-Pythagoreans. In the prologue to Sirach, the hope is expressed that the

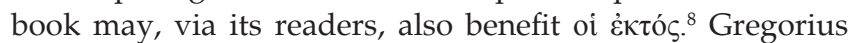
Thaumaturgus (Orig. Orat. Pan sect. 10, lines 15-16) depicts

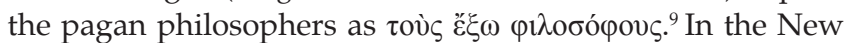
Testament, oi $\check{\varepsilon} \xi \omega$ refers to those not belonging to the Jesus followers: Mark 4:11; 1 Corinthians 5:12-13; Colossians 4:5; 1 Thessalonians 4:12. In 2 Clement 13:1, of है $\xi \omega$ is supplemented

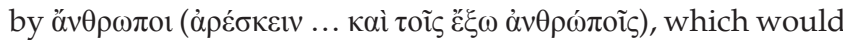
be the fuller form of the phrase. For this investigation, Colossians 4:5; 1 Thessalonians 4:12, as well as 2 Clement 13:1-4, are of special importance.

3.See especially Dibelius ([1921] 1964:18-23); Dibelius ([1933] 1966:239-241) He states: 'Die Regeln und Weisungen ... haben nicht aktuelle sondern usuelle Bedeutung' (239).

4.For example, contrary to a widespread belief, even the Pauline instructions regarding the charismata in Romans $12: 3-8$, are embedded in a problematic situation amongst the Roman Christians - see Du Toit (2010:4).

5.Ground-breaking publications in this regard were those of Van Swigchem (1955) and Van Unnik ([1964] 1980); cf. also Lippert (1968) and Du Toit (1981).

6.Oi $\tilde{\varepsilon} \xi \omega$ and oi $\tilde{\varepsilon} \xi \omega \theta \varepsilon v$ are synonyms, as in Josephus Antiq 15, 314 and 316

$7 . I$ am not convinced by Van Unnik's surmise $(1980: 309$, n. 6) that this term originates from the political sphere.

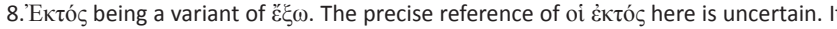
may indicate lay people in contrast to the scribal community (Behm 1935:572) or people outside the Jewish community (Garland 2003:190, n. 3).

9.Behm (1935:572) provides some examples from rabbinic literature.

10.In Colossians 4:5-6 the reaction of outsiders is not specifically mentioned, but it is clearly implied.
Oi $\check{c} \xi \omega \theta \varepsilon v$ is used by Thucydides (Book 5 , ch. 57 , sect. 2, line $3)$ in referring to non-allied forces, whilst Josephus uses it for non-Jews (Bell Jud 4, 179; Antiq 15, 316). In the New Testament, it occurs only in 1 Timothy $3: 7 .{ }^{11}$

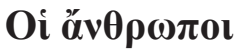

In the New Testament, the general public, which naturally includes those people who do not belong to the Christian ingroup, are often designated as the ö $v \theta \rho \omega \pi$ ot. Some important texts dealing with the ethos expected of Christians towards the öv $\theta \rho \omega \pi \mathrm{or}$ are Matthew 5:16; Romans 12:17-18; 14:18; Philippians 4:5; 1 Timothy 2:1-4; 1 Peter 2:15. Of these, Matthew 5:16 and 1 Peter 2:15 are of special relevance to this investigation.

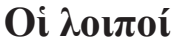

Oi $\lambda$ olлoí occurs fairly often in the New Testament, but only in a few instances is it used to contrast outsiders to disciples or believers: Ephesians 2:3; 1 Thessalonians 4:13; 5:6.12 In these texts the attitude and lifestyle of non-Christians are contrasted to those typical of or expected from Christians. The perlocutionary goal of the comparison is to remind believers that they should radically dissociate themselves from their previous behaviour as non-believers. The influence of the lifestyle of Christians on the 'others' is not in view.

\section{Tò ẓ̌v}

Tò $\ddot{\varepsilon} \theta \mathrm{v} \eta$ occurs prolifically in early Christian literature, but less often in paraenetic contexts. In Matthew 6:32 par Luke 12:30; Ephesians 4:17 and 1 Thessalonians 4:5 we find the same kind of inwardly directed comparison between believers and nonbelievers as in the section Oi $\lambda$ oi $\pi$ oí. However, Romans 2:24 (cit. from Isai 52:5; ${ }^{13}$ ), 1 Peter 2:12; 4:4; 2 Peter 2:2, Ignatius, Letter to the Trallians 8:2 and 2 Clement 13:1-4 are relevant to this investigation.

\section{Varia}

Other formulations that refer to outsiders or include them are

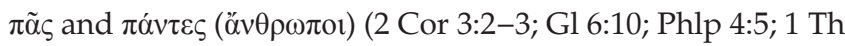

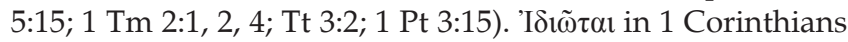

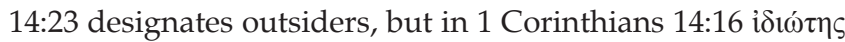
most probably refers to a person who finds himself or herself 'in the role of the novice when someone prays in a tongue' (Garland 2003:641). Even passives may imply non-Christian reaction as in Romans 14:16, 1 Peter 3:16 and Titus 2:5. ${ }^{14}$ In this context, Romans 14:16, 1 Peter 3:15-16 and Titus 2:5 require our attention.

\section{The two main trajectories emerging from the outsider sayings}

The moral instructions contained in the outsider sayings presuppose that those outside the Christian fold possess a

11. However, it appears as a varia lectio in Mark 4:11. Cf. also Pseudo-Justin, Cohort ad

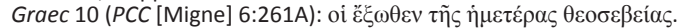

12.Cf. also Luke 8:10. The parallel in Mark 4:11 has oi $\tilde{\varepsilon} \xi \omega$.

13.Cf. also 2 Peter 2:2, echoing Isaiah 52:5 (or perhaps Rm 2:24?).

14.For a further discussion, vide infra. 
natural capacity to evaluate the positive or negative quality of human conduct. This constitutes a norm on the basis of which a decision is made about the inner quality of the Christian faith. ${ }^{15}$ We shall first look at admonitions regarding negative reactions to the unworthy conduct of Christians.

\section{The negative trajectory}

\section{В $\lambda \alpha \sigma \varphi \eta \mu i ́ \alpha / \beta \lambda \alpha \sigma \varphi \eta \mu \varepsilon ́ \omega$}

In Romans 2:17-24, Paul dwells on the nature of Jewish transgression. As a result of Israel's disobedience to the law

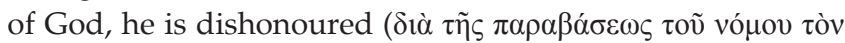

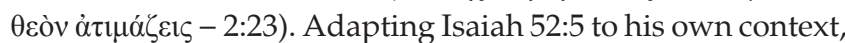
Paul then further spells out the result of the disobedience of the Jewish people: the Name of God is defamed by the

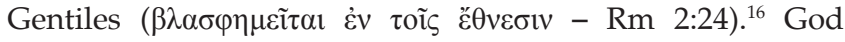
Himself comes into disrepute. 'Israel, whose special vocation it was to sanctify God's Name by its obedience' (Cranfield 1975:171), and thereby draw the Gentiles to Jahwe, actually effected the opposite. Instead of a centripetal movement towards Zion, the Gentiles are driven away.

This $\beta \lambda \alpha \sigma \varphi \eta \mu i ́ \alpha$ motif recurs in various forms and contexts in early Christian paraenesis. In Romans 14, Paul deals with inner-Christian relationships. In 14:16, the 'strong' believers are urged to behave sensitively towards their 'weak' brothers in order to avoid that 'your good ( $(\mu \grave{\eta} \beta \lambda \alpha \sigma \varphi \eta \mu \varepsilon i ́ \sigma \theta \omega)$. ' Within the broader context of Romans, the 'good' which believers possess would be more than just the freedom of the strong. It would include the gospel itself (Cranfield 1975:717; Dunn 1988:831; Schreiner 1998:727). Disregard for the feelings of the weak would not only discredit the ethos of the strong; it would also defame the gospel as such.

The Pastoral letters show a special sensitivity towards the reaction of outsiders. In 1 Timothy 6:1, slaves are instructed to regard their masters with respect 'so that the name of God and the teaching $(\delta 1 \delta \alpha \sigma \kappa \alpha \lambda i \alpha)$ may not be slandered ( $\mu$ iे $\beta \lambda \alpha \sigma \varphi \eta \mu \tilde{\eta} \tau \alpha)$. Likewise the young wives should fulfil their roles in an exemplary way 'so that the word of God may not be slandered ( $\mu$ ì $\beta \lambda \alpha \sigma \varphi \eta \mu \tilde{\eta} \tau \alpha)$ ' (Tt 2:5).

1 Peter displays the same sensitivity. The addressees are a minority group living in an abusive, suspicious non-Christian society (cf. esp. Elliott 1981:59-100; Richard 2004:412-414). For the Christian cause it is of critical importance that Christians should behave correctly. However, in 1 Peter 4:4 the unexpected happens. The pagans react negatively to the blameless behaviour of their former associates in immoral activities. Envy, and perhaps also a guilty conscience, seem to have provided them with some bizarre motivation for reviling, (cf. $\beta \lambda \alpha \sigma \varphi \eta \mu о \tilde{v} \tau \varepsilon \varsigma)$ even a positive lifestyle.

15.Cf. also Brox (1979:113). Wohlenberg stated aptly that also non-Christians 'auf Grund ihres Gewissens eine starke Empfindung für das besitzen und bekunden, was sittlich gut und böse ist' (1915:215). However, it was Malherbe who drew attention to the many similarities between Christian and pagan morality. See especially Malherbe (2000:229-230, 233, 243-260, 303-306).

16.In Ezekiel (36:20-23) this theme is further developed. The nations had lofty expectations of the people of Jahwe, but through their sins Israel profaned his holy Name.
James 2:7 does not function within a paraenetic context, but the same motif is apparent: the addressees are told that the misconduct of the rich causes the defamation (cf. $\beta \lambda \alpha \sigma \varphi \eta \mu о \tilde{\sigma}(v)$ of 'the good Name which was invoked over you.' We find the same in 2 Peter 2: Many will follow the licentious ways of the false prophets and because of them 'the way of truth will be slandered ( $\beta \lambda \alpha \sigma \varphi \eta \mu \eta \theta \dot{\gamma} \sigma \varepsilon \tau \alpha)$.'

According to 1 Clement 47:6-7, the report of the unworthy conduct of the Corinthian congregation (sedition against their presbyters) has reached not only the Roman believers

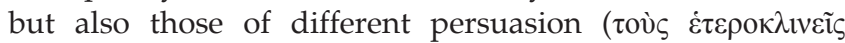

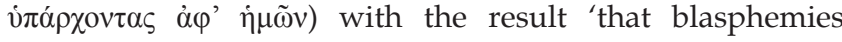
( $\left.\beta \lambda \alpha \sigma \varphi \eta \mu i_{\alpha}\right)$ are brought upon the Name of the Lord.'

However, it is in 2 Clement 13 that the $\beta \lambda \alpha \sigma \varphi \eta \mu$ í $\alpha$ theme reaches its climax. Here it is repeated no less than six times. When the lifestyle of Christians belie the high standard expected of them and which they preach themselves, the

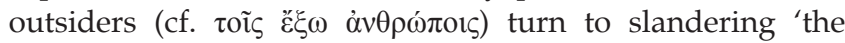
Name'. The reason for this is their disillusionment. The Gentiles were led to have high expectations of the Christian ethos. But when they notice the discrepancy between Christian preaching and conduct they react vehemently:

For the Gentiles, when they hear the words of God, marvel at their beauty and greatness. When they then discover that our works are not worthy of the words we speak, they henceforth turn to slander ( $\varepsilon i \varsigma \beta \lambda \alpha \sigma \varphi \eta \mu i ́ \alpha v$ ), saying that it is a myth and delusion. For when they hear from us that God says: 'You do not have credit if you love those that love you; but you will have credit if you love your enemies and those who hate you' - when they hear these things, they marvel at their surpassing goodness. But when they see that we not only do not love those who hate us, but even those who love us, they ridicule us and the Name is slandered ( $\beta \lambda \alpha \sigma \varphi \eta \mu \varepsilon i ̃ \alpha$ เò òvo $\mu \alpha)$. (2 Clement 13:3-4)

I conclude this part of my presentation with Ignatius' Letter to the Trallians 8:2. The author calls upon his addressees 'to

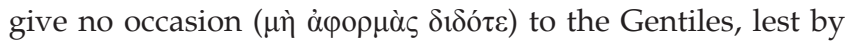
reason of a few foolish men the godly multitude (the church) may be slandered $(\beta \lambda \alpha \sigma \varphi \eta \mu \varepsilon i \tau \alpha))^{\prime}$ Then follows a citation ${ }^{17}$

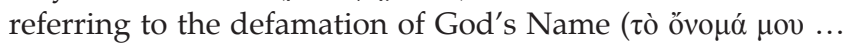
$\beta \lambda \alpha \sigma \varphi \eta \mu \varepsilon i \tau \alpha \iota)$.

We were able to follow a significant number of statements centering around the $\beta \lambda \alpha \sigma \varphi \eta \mu$ í $\alpha$ theme, which took its cue from Isaiah 52:7 and occurred from Paul ${ }^{18}$ through the latter part of the first century up to the first decades of the second century. Despite contextual and other variations, the basic tenet remains the same: if Christians do not live up to rightful expectations it has critical consequences. These are spelt out to cover a broad spectrum, namely (1) the Name of God, ${ }^{19}$ (2)

17.The origin of this quotation, which also appears in 2 Clement $13: 2$ and elsewhere, is unknown - Donfried (1974:53, 86-88); Gregory and Tuckett (2005:281). Van Unnik ([1964] 1980:312-314) discusses the various early Christian occurrences of this enigmatic indictment at length and finally concludes that it must have originated from a 'prophetic-apocalyptic' writing which was 'in vielem dem Henochbuch gleichartig' ([1964] 1980:314).

18.There is no indication of literary dependence on Paul. We should rather reckon with a broad common Christian tradition which originated with Isaiah 52:7, and for which Paul, as Christian author, may or may not have acted as catalyst.

19.Donfried (1974:154-159) impressively argues that 'the Name' in 2 Clement 13 actually refers to Jesus Christ, who is regarded as fully on a par with God. However in the light of the foregoing tradition which consistently referred to God, a final conclusion is difficult. 
the gospel, (3) Christian teaching and (4) the church, in short, the Christian cause in its totality, is not only discredited in the eyes of non-believers but also elicits their contempt. Words are not enough. The gospel message should be exemplified and validated by an exemplary lifestyle. Otherwise Christian belief can no longer claim credibility and respect.

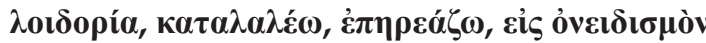

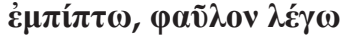

In much the same spirit as Titus 2:5, 1 Timothy 5:14 urges the young women to marry, raise children and manage a household in order not to give the enemy occasion for reviling

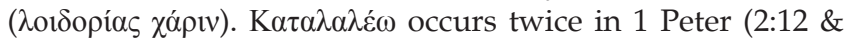
$3: 16)$. The first verse refers to hostile pagan neighbours who

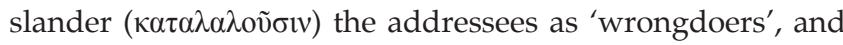
the latter simply mentions that the addressees are 'being

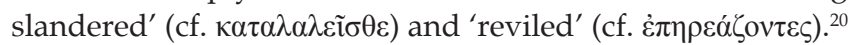
1 Timothy 3:7 visualises that a good reputation will counter

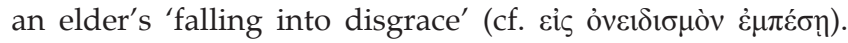
According to Titus 2:7-8, the young men should set an example of positive conduct so that 'the opponent may be put to shame since he has nothing bad to say ( $\mu \eta \delta \varepsilon \dot{\varepsilon} v$ है $\chi \omega v$ $\lambda \dot{\varepsilon} \gamma \varepsilon ı v$... $\varphi \alpha \tilde{\lambda} \lambda \mathrm{ov}$ ) about us.' These formulations will be minor variations on the $\beta \lambda \alpha \sigma \varphi \eta \mu$ í $\alpha$ theme.

\section{The positive trajectory}

This trajectory focusses on the (envisaged) positive reaction of outsiders to an exemplary Christian lifestyle.

\section{The glorification of God}

This theme, which appears in Matthew 5:16 and 1 Peter 2:12, is the positive collorary to the blasphemy motif discussed above. Here we do not have a definite Old Testament point of departure. The Testament of Naphtali 8:4 contains a striking parallel:

If you work that which is good, my children,

both men and angels will bless you

and God will be glorified through you among the Gentiles

and the devil will flee from you

and the wild beasts will fear you

and the Lord will love you

and the angels will cleave to you. (Translation by Hollander \& De Jonge 1985:317)

However, there exist so many uncertainties around the development history of the Testaments of the Twelve Patriarchs, ${ }^{21}$ that the nature of the relationship between Matthew 5:16, 1 Peter 2:12 and the glorification motif in the Testament of Naphtali is unclear. We shall first give attention to Matthew 5:16.

Matthew 5:16: Matthew 5:13-16, which is the result of intensive redactional activity on the part of Matthew, ${ }^{22}$ is much more than a mere transition from the beatitudes to the major passage Matthew 5:17-48. It is in fact a nexus passage

20.For an overview of the forms of hostility to which the addressees of 1 Peter were exposed, see Elliott (1981:79-81).

21.Cf. the extensive overview in Hollander and De Jonge (1985:10-83).

22.Gundry (1982:75-78); Luz (1985:219-220). which harks back to 5:11-12 and prepares for 5:17-48. The poetic pattern of the beatitudes changes at verse 11, and the beneficiaries are now unexpectedly directly addressed (cf. the second person plural). This implies that the Jesus followers of verses 11-12 are the same as the v $\mu \varepsilon i \bar{\varsigma}$ of verses 12 and 14. The people insulted and persecuted and falsely spoken of, precisely these are the salt of the earth et cetera (cf. Luz 1985:219-221). At the same time, 5:13-16 forms the programmatic heading for the whole of 5:17-48. It is in fact a concise characterisation of the function of the Jesus followers

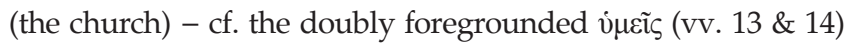
- in the world, the nature of which is then spelled out at length in 5:17-48. ${ }^{23}$

Three metaphors come into play: salt, light and a city on the hill. The light metaphor finds its climax in 5:16, where it is concretisised as the $\kappa \alpha \lambda \grave{\alpha} \grave{\varepsilon} \rho \gamma \alpha$ which the Jesus followers should perform and on account of which the oi óv $\theta \rho \omega \pi$ or will glorify ( $\delta \mathrm{o} \xi \alpha \dot{\alpha} \sigma \sigma \mathrm{v})$ God. In these four verses the importance of exemplary Christian living is impressively highlighted.

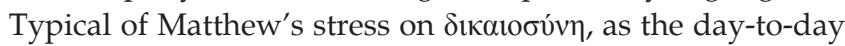
obedience to and fulfilment of the will of God, the calling of the Jesus followers in the world is here pictured as a 'Christianity of being', a 'lived proclamation'. The i $\mu \varepsilon i \bar{c}$ is certainly not only directed to the Matthaean church; the references to the 'earth' and the 'world' (cf. also the ơ $v \theta \rho \omega \pi \mathrm{or}$ ) indicate that this 'mission ${ }^{24}$ by the deed' is the task of the Christian church at large. And the purpose of this mission is formulated as the glory of God. Luz correctly says: 'Es gibt nur wenige Texte im Neuen Testament, wo die Ehre Gottes so deutlich Zielpunkt des gesamten christlichen Handelns ist' (1985:225).

1 Peter 2:12: This verse shows substantial verbal and other

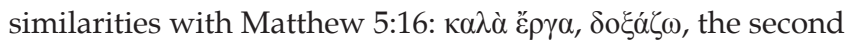

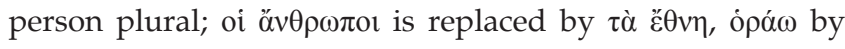

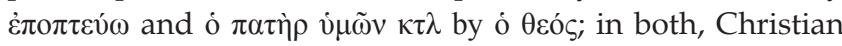
ethos within a hostile environment is at issue..$^{25}$ Whether this correspondence is due to a common tradition (Brox 1979:114) or literary dependence on the part of 1 Peter (Luz 1985:220) is not easy to decide and anyway not of consequence here. ${ }^{26}$

Interestingly enough, the positive and negative trajectories converge in 1 Peter 2:12. The scenario is that the non-Christian neighbours experience the Christian minority as an irritating corpus alienum in their midst which formerly took part in their public, social and synchretistic religious activities, but are now refusing to compromise; they are different and act differently. The reaction of the non-Christians is to revile the

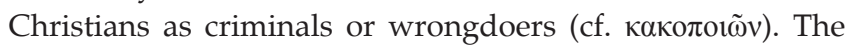

23.See Du Toit (1966:203-204). Zahn (1910:301) even called 5:16 the summa of the sermon on the mount. Luz (1985:219), referring to Zahn, depicts 5:16 as some kind of title to 5:17-48. However, this verse should not be isolated. The whole of 5:13-16 functions in this way, although verse16 forms its climax. 6:1 echoes 5:16, and rectifies a possible misinterpretation of the 'good works' (cf. Luz 1985:219).

24.I use the terms 'mission'and 'missionary' in the traditional sense of the endeavour to win non-Christians over to the Christian faith.

25. Also the concrete manifestation of the hostility (cf. 'to speak evil' [Mt 5:11] and 'to slander as wrongdoers' [1 Pt 2:12]), show a striking similarity. However, 1 Peter does not mention persecution.

26.The correspondence is so striking that I am inclined to agree with Luz; compare also Matthew 5:10 and 1 Peter 3:14; 4:14. 
latter are in fact suffering verbal abuse, defamation, charges of antisocial behaviour and social ostracism. However, if the addressees would persist with 'good works', as the author

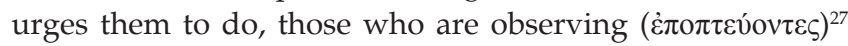
their honourable conduct will eventually realise their mistake and turn to praising God. The participial qualification $\dot{\varepsilon} v \dot{\eta} \mu \varepsilon^{\prime} \rho \alpha$ $\dot{\varepsilon} \pi \iota \kappa \kappa \pi \tilde{\eta} \varsigma$ most probably refers to God's merciful visitation (Brox 1979:115). Honourable conduct implies that Christians should not shirk their sociopolitical responsibilities, but perform these in a praiseworthy manner. In 2:16-17 their ethos as 'servants of God' is summarised as honouring all fellow humans, loving the Christian brotherhood, revering God and honouring the public authority ( $\operatorname{cò} \nu \beta \alpha \sigma 1 \lambda \varepsilon \dot{\varepsilon} \alpha \tau \mu \alpha \tilde{\tau} \tau)$ (2:16-17) (cf. Richard 2004:419-420).

\section{Silencing the critics - putting them to shame}

According to 1 Peter 2:15, the exemplary conduct of Christians will eventually result in silencing the opponents: 'For it is God's will that by doing good you should silence (cf. $\varphi \mu$ iṽv) the ignorance of foolish people.' In 3:15-16 there is a similar injunction: when Christians give an account of their faith to those who enquire about it, they should do it 'with courtesy and respect, keeping a good conscience, so that those who

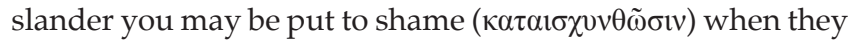
revile your good conduct in Christ.'

We find more or less the same tenor in Titus 2:8, but here the Christian message ( $\lambda$ ó $\gamma \circ \varsigma$ ) is in view: it should be 'sound

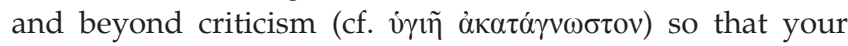

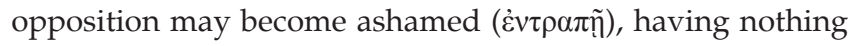
bad to say about us.' However, it would be wrong, within this context, to contrast the right teaching of verse 7 and the sound message of verse 8 with the $\kappa \alpha \lambda \grave{\alpha}$ है $\gamma \gamma \alpha$ of which

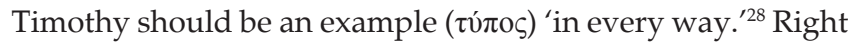
teaching and preaching are here seen as part of the $\kappa \alpha \lambda \grave{\alpha}$ है $\gamma \gamma \alpha$ ! Thus the opposition should be confronted by an integrated example, consisting of the one gospel lived and spoken, and thus be put to shame.

\section{Gaining the respect of outsiders or having a good reputation}

1 Thessalonians 4:12 goes somewhat further: a positive lifestyle could even gain the respect of outsiders. Paul addresses a concrete problem in the congregation of Thessalonica. Some members were acting disorderly, meddling in other people's affairs, surrendering themselves to idleness and consequently became dependent on others (4:11-12). This exposed not only themselves but the whole congregation to criticism from the outsiders. They are therefore exhorted to lead an

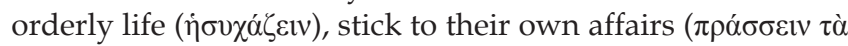

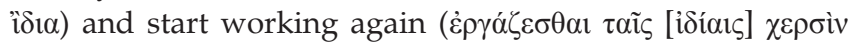
$\dot{\nu} \mu \tilde{\omega} v)$ 'so that your conduct may be becomingly in the eyes of the outsiders.' This will gain the respect of their neigbours. The New International Version accordingly translates: 'so that your daily life may win the respect of outsiders' (cf. also the Revised English Bible).

27.Goppelt (1978:160) correctly interprets the present participle as ein länge andauerndes, reflektierendes Beobachten.'

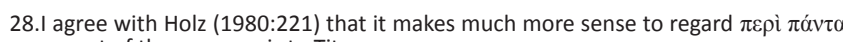
as part of the paraenesis to Titus.
1 Timothy 3:7 requires of an overseer that he should have 'a good reputation with the outsiders.' From the context, the concern is clear that an overseer should have proven himself over a prolonged period as a stable person, as a man of integrity. A parvenu could easily, not only disgrace himself, but also the congregation.

\section{'Adorning' the teaching of God}

This appealing metapher appears in Titus 2:10 in connection with the behaviour required of Christian slaves. Although the outsiders are not specifically mentioned, ${ }^{29}$ they are implied. Titus 2:9-10 reminds us of the New Testament Haustafel, but does not really fit into the typical scheme (Holtz 1980:216). Addressing the slaves, they are exhorted to be submissive to their masters, to please them without 'back-talking' (cf. $\mu \eta \grave{\alpha} \nu \tau \imath \lambda \dot{\varepsilon} \gamma o v \tau \alpha \varsigma)$ or pilfering and to show that they can be

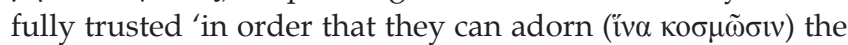
teaching of God our Saviour in every way.' By their positive behaviour the slaves should make the gospel attractive to those outside.

\section{'Winning' the outsiders for the faith}

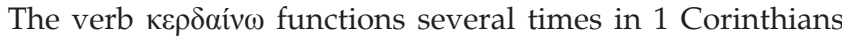
9:19-22 (cf. Mt 18:15) as a missionary term. ${ }^{30}$ It appears with reference to the 'winning' of an outsider in the remarkable statement of 1 Peter 3:1-2:

In the same way, wives, be submissive to your husbands so that, if some of them do not believe the word, they may be won over

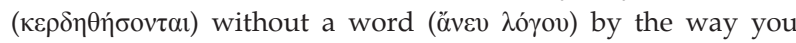
[litt. the wives] live, when they observe your reverent and pure conduct.

Nowhere in the New Testament is belief in the persuasive power of an exemplary lifestyle expressed more forcefully than here. The ongoing debate around the rights of women concentrates so heavily on the position of women that the persuasive force of a wife's exemplary lifestyle in this text is often overlooked.

\section{The perlocutionary aim of the outsider sayings}

Studies of early Christians paraenetic texts, referring to the reaction of outsiders, are inclined to read a missionary focus into each and every of these injunctions. However, caution

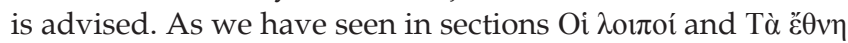
above, texts which contrast the lifestyle of believers with that of non-believers are usually directed inwardly, aimed at reinforcing the ethical quality of congregational life and thus the cohesion, identity and good reputation of the believing community. We should therefore reckon with the possibility that at least some of the outsider sayings which we discussed above, have an inwardly directed thrust. At the same time we should ask whether a strict either/or approach does justice to the inherent nature of these sayings. A real quality congregational and individual ethos would, in the nature of

29.See also 1 Timothy 2:9-10, where the adornment of Christian wives consists of their 'good works'.

30.See Schlier (1967:672). 
things, also be attractive to outsiders. This would explain why it is often so difficult or even impossible to decide whether a specific injunction has a 'centrifugal' or a 'centripetal' thrust, or in fact covers both. In the latter case, one possibility may be articulated explicitly whilst the other remains implicit, and vice versa. It would therefore be wise to distinguish only between, say, a primary centrifugal or missionary focus on the one hand and a primary centripetal or inward focus on the other.

\section{Injunctions with a primary inward thrust}

In moral admonishments with a primary inward thrust the projected reaction of outsiders is intended as a persuasive device to strengthen the moral commitment of the addressees. In these instances, apologetic considerations may also come into play. I shall present only a few examples of this kind of paraenesis.

We first turn to the prominent outsider passage of 2 Clement 13. Van Unnik ([1964] 1980:310) emphatically denied that this passage has a missionary purpose. He is probably correct in the sense that these ethical exhortations certainly have a primary inward focus. 2 Clement is directed towards clarifying and improving inner-congregational matters (Donfried 1974: 98-181). It is in fact a strong call to repentance (cf. esp. 8; 9:8; $13: 1 ; 16: 1 ; 17: 1 ; 19: 1)$, and focusses strongly on improving the ethos of believers. The confession of Christians should consist, not in their words, but in their works (3:4 and 4:3). 2 Clement 17:1 does mention that Christians 'have received commands ... to tear men away from idols', but the focus falls on what follows: 'how much more is it wrong that a soul that knows God already should perish!' This inward directedness is also dominant in 13:1ff. The really sensitive point seems to be that the church members do not only disobey God's command that they should love their enemies, they do not even love one other (13:4). The focus clearly is on undergirding the ethos of the addressees. On the other hand, it would overstrain the limits of the linguistic process to categorically deny that some missionary undertone may have been communicated. The concern for the honour of 'the Name' amongst the outsiders may have done exactly this.

Colossians 4:5-6 and 1 Peter 3:15 probably belong to the same category. Eduard Schweizer (1976:173-174), like many before him (e.g. Van Swigchem 1955:126-128), has no hesitation in interpreting the Colossians' passage from a missionary perspective. Conducting themselves with 'wisdom towards outsiders' and answering everyone graciously form part of the missionary responsibility of Christians. Already Van Unnik ([1964] 1980:315-316) criticised this interpretation. The focus is on ethics and not on missionary activity. Michael Wolter (1993:211-213) agrees with this and even labels the missionary reading as eisegesis. However, both reckon with an apologetic slant in the paraenesis. In my opinion, a close reading of this passage confirms this. The focus is on exemplary conduct which gives a positive account of the Christian faith. However, once again a possible missionary undertone cannot categorically be ruled out. The same holds true of 1 Peter 3:15. Significantly, this passage even uses the word $\alpha \operatorname{\alpha } \mathrm{\nu} \hat{\mathrm{\gamma}} \gamma 1 \alpha$.

\section{Injunctions with a primary missionary thrust}

Some of the outsider sayings in this study have a decidedly missionary thrust. Naturally they deal with the moral behaviour expected of Christians, but they highlight the envisaged missionary effect of such exemplary conduct.

The missionary thrust of Matthew 5:16 is abundantly clear. The goal of the 'good works' is that the outsiders will come to praise God. Ulrich Luz unhesitatingly states: 'Die Werke der Christen haben missionarische Funktion' (1985:225). In the closely related 1 Peter 2:12, the glorification of God is equally accentuated, but not everyone would agree that this verse has a missionary intention. The interpretation of the phrase $\dot{\varepsilon} v \dot{\eta} \mu \varepsilon \dot{\varepsilon} \rho \dot{\varepsilon} \pi \iota \sigma \kappa о \pi \tilde{\eta} \varsigma$ is the bone of contention. Is this 'day of visitation' an occasion of grace (e.g. taking place in the personal lives of the non-Christians) or one of judgement (e.g. on judgement day)? Balch (1981:87), following Van Unnik, points out that 1 Enoch 62-63 describes the gentiles glorifying God at the judgement, but nevertheless being condemned, and concludes that he can find no reference to the conversion of pagans. However, this is a one-sided view. In Luke 19:44, каıро̀ $\tau \tilde{\eta} \varsigma \dot{\varepsilon} \pi 1 \sigma \kappa о \pi \tilde{\eta} \varsigma$ is used in the sense of a gracious visitation by God and $\dot{\eta} \mu \varepsilon \dot{\rho} \rho \alpha \dot{\varepsilon} \pi \iota \sigma \kappa о \pi \tilde{\eta} \varsigma$ could easily have the same positive meaning. ${ }^{31}$ If we compare 1 Peter 2:12 with 3:1-2 it becomes clear that we basically have the same train of thought: recommended conduct ( $\dot{\alpha} v \alpha \sigma \tau \rho \circ \tilde{\eta})$

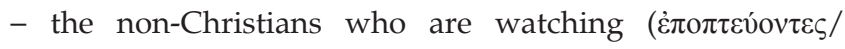
$\dot{\varepsilon} \pi \mathrm{o} \pi \tau \varepsilon v ́ \sigma \alpha \nu \tau \varepsilon \varsigma)$ - a positive result. In 1 Peter 3:1 this result is formulated as the 'winning' of the husbands. In 2:12 the result will be similar - the conversion of those who previously slandered the addressees. Even if the 'day of visitation' would be judgement day it would imply that the gentiles, as those who have already been converted, will at that day glorify God. ${ }^{32}$

'Winning' the outsider (1 Pt 3:1-2) $)^{33}$ and 'adorning' the Christian teaching ( $\mathrm{Tt} 2: 10)$ will also have a missionary edge. ${ }^{34}$ 1 Thessalonians 4:12 is uncertain. Malherbe (2000:259), for instance, is convinced that 'Paul is simply urging his readers to a certain behaviour in the concrete context in which they live.' There is no indication here that Christian conduct has an 'evangelical thrust' [ibidem]. On the other hand, one may ask whether 'gaining the respect' of outsiders is not moving in a missionary direction. There is, at any rate, an apologetic note present. In fact, most, if not all, of the outsider

31.Cf. the well-balanced presentation by Beyer (1960:603-604).

32.See also the positions of Goppelt (1978:161-162); Brox (1979:113-115), both being, in the main, positive.

33.Cf. also 1 Corinthians 7:16

34.Ignatius' Letter to the Ephesians 10:1 falls in the same category: 'Pray unceasingly Ignatius' Letter to the Ephesians 10:1 falls in the same category: 'Pray unceasingly
for the other people - for there is in them [or: for them] a hope of repentance for the other people - for there is in them [or: for them] a hope of repentance
- that they may find God. Let them therefore learn from you [or: become your - that they may find God. Let them 
sayings which we have discussed in this paper contain an apologetic element. And apologetics often reflect a missionary concern. ${ }^{35}$

\section{Conclusion}

In many modern countries the Christian message has become discredited. In post-apartheid South Africa, for instance, the gospel on the lips of White South Africans is distrusted. In the rest of Africa, South America and Western countries other factors contribute to the negative perceptions. The most effective way to counter this negativity is by means of what can be called 'indirect proclamation', ${ }^{36}$ which means that Christians should preach the gospel through exemplary living. By our integrity, by our living the gospel, by our humble, loving, selfless service, 'the others' could possibly be convinced. In 2 Corinthians 2:2-3, Paul pictures Christians as a letter of recommendation 'known and read by all'. Should Christians through the ethical quality of their lives become such a letter, this world could become a better place for all. Vita pii evangelium populi.

\section{Acknowledgements Competing interests}

The author declares that he has no financial or personal relationship(s) which may have inappropriately influenced him in writing this article.

\section{References}

Ascough, R.S., 2007, 'Defining community-ethos in light of the "other": Recruitment rhetoric among Greco-Roman associations', Annali di storia dell' exegesi 24, 59-75.

Balch, D.L., 1981, Let wives be submissive - The domestic code in 1 Peter, Scholars Press, Chico. (Society of Biblical Literature Monograph Series, 26).

Behm, J., 1935, ' $\varepsilon \xi \omega$ ', Theologisches Wörterbuch zum Neuen Testament 2 Kohlhammer, Stuttgart, pp. 572-573.

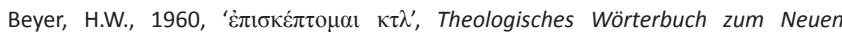
Testament 2, Kohlhammer, Stuttgart, pp. 595-619.

Brox, N., 1979, Der erste Petrusbrief, Benziger Verlag, Zürich/Einsiedeln/Köln Neukirchener Verlag, Neukirchen-Vluyn. (Evangelisch-Katholischer Kommentar 21).

Cranfield, C.E.B., 1975, A critical and exegetical commentary on the Epistle to the Romans, T \& T Clark, Edinburgh. (The International Critical Commentary).

Crook, Z.A. \& Harland, P.A. (eds.), 2007, Identity and interaction in the ancien Mediterranean - Jews, Christians and others: Essays in Honour of Stephen G. Wilson, Sheffield Phoenix, Sheffield.

Dibelius, M., [1921] 1964, Der Brief des Jakobus, 11th edn., Vandenhoeck \& Ruprecht, Göttingen. (Kritisch-Exegetischer Kommentar über das Neue Testament 15).

Dibelius, M., [1933] 1966, Die Formgeschichte des Evangeliums, 5th edn., Mohr, Tübingen.

Donfried, K.P., 1974, The setting of Second Clement in Early Christianity, Brill, Leiden (Novum Testamentum Supplementa, 38).

Dunn, J.D.G., 1988, Romans 1-8, Word Books, Dallas. (Word Biblical Commentary, 38).

Dunning, B.H., 2009, Aliens and Sojourners. Self as Other in Early Christianity, University of Pennsylvania Press, Philadelphia. (Divinations: Rereading Late Ancient Religion).

$35.1 \mathrm{t}$ is a grave misconception to regard Christian apologetics as intended exclusively to reassure and strengthen insiders. Friedrich Schleiermacher's famous apology for Christianity, as he understood it, was after all not directed to adherents of the Christian faith, but to its 'educated despisers' (cf. the title of his work: Über die Religion. Reden an die Gebildeten unter ihren Verächtern - see Schleiermacher 1899).

36.See in this regard especially Klauck (2005).
Du Toit, A.B., 1966, 'The nature of the witness of the church in the world according to Matthew 5:13-16', in A.H. Van Zyl (ed.), Biblical Essays 1966, pp. 200-218, Pro Rege, Potchefstroom.

Du Toit, A.B., 1981, 'Die geloofwaardigheid van die kerk as faktor in sy verkondiging in die lig van die Nuwe Testament', Nederduitse Gereformeerde Teologiese Tydskrif 22, 166-178.

Du Toit, A.B., 2010, 'Some more translation problems in Romans', Verbum et Ecclesia 31, 1-5. http://dx.doi.org/10.4102/ve.v31i1.385

Elliott, J.H., 1981, A home for the homeless: A sociological exegesis of 1 Peter, its situation and strategy, Fortress Press, Philadelphia.

Garland, D.E., 2003, First Corinthians, Baker Academic, Grand Rapids. (Baker Exegetical Commentary on the New Testament).

Goppelt, G., 1978, Der Erste Petrusbrief, Vandenhoeck \& Ruprecht, Göttingen. (Kritisch-Exegetischer Kommentar über das Neue Testament, 12/1).

Gregory, A. \& Tuckett, C. (eds.), 2005, The reception of the New Testament in the Apostolic Fathers, Oxford University Press, New York. (The New Testament and the Apostolic Fathers).

Gundry, R.H., 1982, Matthew. A commentary on his literary and theological art. Eerdmans, Grand Rapids.

Hollander, H.W. \& De Jonge, M., 1985, The Testament of the Twelve Patriarchs: A commentary, Iohannes Naeranus, Rotterdam. (Studia in Veteris Testamenti pseudepigrapha; v. 8).

Holtz, G., 1980, Die Pastoralbriefe, 3. Aufl. Evangelische Verlagsanstalt, Berlin (Theologischer Handkommentar zum Neuen Testament 13).

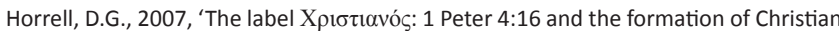
identity', Journal of Biblical Literature 126, 361-381.

Klauck, H-J., 2005, 'Nicht durch das Wort allein - neutestamentliche Paradigmen indirekter Verkündigung', Münchener Theologische Zeitschrift 56, 194-211.

Kopas, J., 1993, 'Outsiders in the Gospels', Way 33, 117-126.

LaHurd, C.S., 1997, 'The "other" in biblical perspective', Currents in Theology and Mission 24, 411-424.

Lippert, P., 1968, Leben als Zeugnis: Die werbende Kraft christlicher Lebensführung nach dem Kirchenverständnis neutestamentlicher Briefe, Katholisches Bibelwerk, Stuttgart. (Stuttgarter Biblische Monographien 4).

Luz, U., 1985, Das Evangelium nach Matthäus (Mt 1-7), Benziger Verlag, Zürich/ Einsiedeln/Köln, Neukirchener Verlag, Neukirchen-Vluyn. (EvangelischKatholischer Kommentar zum Neuen Testament, 1/1)

Malherbe, A.J., 2000, The letters to the Thessalonians, Doubleday, New York. (Anchor Bible 32B).

Metzger, M., 2006, 'Les chretiens des premiers siècles et "ceux du dehors"', Revue des sciences religieuses $80,155-166$.

Neusner, J. \& Frerichs, E.S. (eds.), 1985, To see ourselves as others see us: Christians, Jews, 'others' in Late Antiquity, Scholars Press, Chico.

Pietersen, L.K., 2004, The polemics of the Pastorals, Clark, London/New York.

Richard, E.J., 2004, 'Honorable conduct among the Gentiles - A Study of the social thought of 1 Peter', Word and World 24, 412-420.

Schleiermacher, F.E.D., 1899, Über die Religion: Reden an die Gebildeten unter ihren Verächtern. Herausgegeben von, R. Otto.

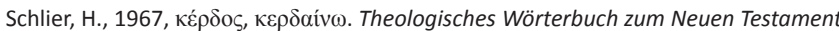
3, Kohlhammer, Stuttgart, 671-672.

Schreiner, T.R., 1998, Romans, Grand Rapids, Baker Books. (Baker Exegetical Commentary on the New Testament 6).

Schwarz, R., 2006, 'Fernstehenden in christlichen Gemeinden: Überlegungen zu Anlass-Gottesdiensten', Heiliger Dienst 60, 40-48.

Schweizer, E., 1976, Der Brief an die Kolosser, Benziger Verlag, Zürich/Einsiedeln/Köln, Neukirchener Verlag, Neukirchen-Vluyn. (Evangelisch-Katholischer Kommentar zum Neuen Testament).

Stolz, F., 2001, 'Das Urchristentum - die Aussenansicht eines Insiders: Zu Gerd Theissens Theorie des Urchristentums', Evangelische Theologie 61, 476-480.

Van Swigchem, D., 1955, Het missionair karakter van de christelike gemeente volgens de brieven van Paulus en Petrus, J.H. Kok, Kampen.

Van Unnik, W.C., [1964] 1980, Die Rücksicht auf die Reaktion der Nicht-Christen als Motiv in der altchristlichen Paränese, in Sparsa Collecta. The Collected Essays of W.C. van Unnik: Part Two, pp. 307-322, E.J. Brill, Leiden. (First published in Eltester W. [Hrsg.] 1964. Judentum-Urchristentum-Kirche. Festschrift für Joachim Jeremias, A. Töpelmann, Berlin, 221-234).

Wohlenberg, G., 1915, Der erste und zweite Petrusbrief und der Judasbrief, Deichert, Leipzig. (Kommentar zum Neuen Testament 15).

Wolter, M., 1993, Der Brief an die Kolosser, Der Brief an Filémon, Gütersloher Verlagshaus, Würzburg; Echter Verlag, Gütersloh. (Ökumenischer TaschenbuchKommentar zum Neuen Testament 12).

Zahn, Th., 1910, Das Evangelium des Matthäus, Deichert, Leipzig. 